\title{
A SPORTTEHETSÉG FELISMERÉSÉNEK ÉS FEJLESZTÉSÉNEK PSZICHOLÓGIAI ALAPJAI (RECENZIÓ)
}

\author{
A recenzió szerzője: \\ Gerhát Réka \\ Debreceni Egyetem
}

Szerző e-mail címe: gerhatreka@gmail.com

\section{Lektorok:}

Mező Ferenc

Debreceni Egyetem

Balázs Katalin

Debreceni Egyetem

Mező Katalin

Debreceni Egyetem

Nemes Magdolna

Debreceni Egyetem

Gerhát Réka (2016): A sporttehetség felismerésének és fejlesztésének pszichológiai alapjai (Recenzió). Különleges Bánásmód, II. évf., 2016/3. szám, 103-104. DOI 10.18458/KB.2016.3.103

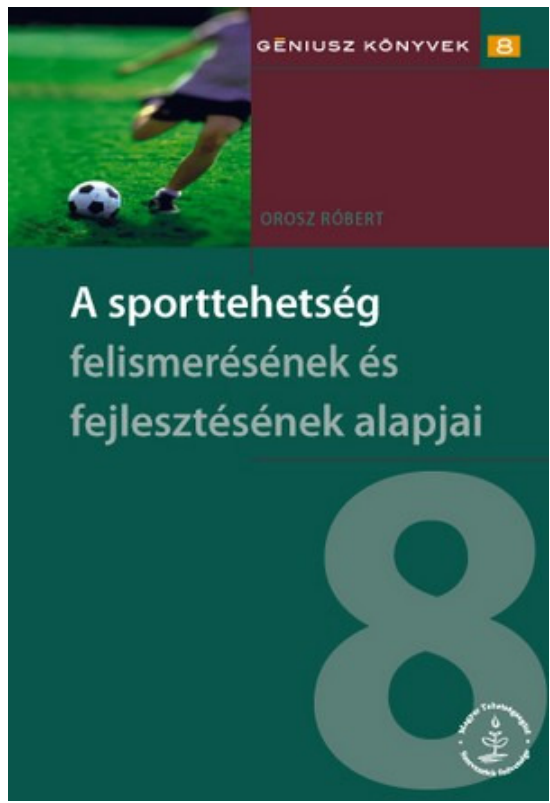

A recenzió alapjául szolgáló mü bibliográfiája:

Orosz Róbert (2010): A sporttehetség felismerésének és fejlesztésének pszichológiai alapjai. Magyar Tehetségsegítő Szervezetek Szövetsége, Budapest. 90 oldal, ISSN: 2062-5936

Kulcsszavak: tehetség, sportpszichológia, sporttehetség, tehetségdiagnosztika, tehetséggondozás

Diszciplinák: pszichológia, pedagógia

Bibliography of the subject of this recension:

Orosz Róbert (2010): A sporttehetség felismerésének és fejlesztésének pszichológiai alapjai. Magyar Tehetségsegítő Szervezetek Szövetsége, Budapest. pp. 90, ISSN: 2062-5936

Keywords: giftedness, sport psychology, sports talent, diagnostic assessment, talent management

Disciplines: psychology, pedagogy

Ajánlom pszichológusoknak, pedagógusoknak, edzőknek, sportolóknak és minden olyan érdeklődő olvasónak, aki szeretne komplex képet kapni a sporttehetség azonosításának és fejlesztésének jelentőségéröl és lehetőségeiröl A sporttehetség felismerésének és fejlesztésének pszichológiai alapjai címü könyvet, mely a Géniusz sorozat köteteinek részét képezi. 
A Géniusz Könyvtár a Magyar Tehetségsegítő Szervezetek Szövetsége által koordinált Magyar Géniusz Program keretében megjelentetett kötetekből tevődik össze. A sorozat célja, hogy segítséget és átfogó eligazítást adjon a tehetséggondozás ügyében tevékenykedö szakembereknek.

A szerző, Orosz Róbert (PhD) gyakorló pszichológus, 2000 óta tehetségpszichológia-oktató a Debreceni Egyetem Pszichológiai Intézetében, 2015-től a Debreceni Labdarúgó Akadémia pszichológusa. 1999 és 2009 között a DMJV Egészségügyi Szolgálat Gyermek- és Ifjúságpszichiátriai Ambulanciáján pszichológus, 2010-11 között a Kék Bolygó Tehetségpont szakmai vezetője, a 2013-14-es szezonban pedig a DVSC TEVA csapatpszichológusaként dolgozott. Élete során tevékenykedett többek között edzőként taekwondo olimpiai sportágban, volt nemzeti válogatott és háromszoros Magyar Bajnok.

Kijelenthetjük, hogy napjainkban egyre nagyobb hangsúlyt kap az emberek fizikai képességeinek fejlesztése-, és tökéletesítése szempontjából elengedhetetlen pszichológiai aspektus. Központi kérdéssé vált, hogy mely tényezők és hogyan játszhatnak igazán szerepet abban, hogy egy sportoló minél jobban ki tudja teljesíteni képességeit, és hogy milyen eszközökkel akadályozható meg a sporttehetség elkallódása.

Az általam ajánlott könyv azért is különösen figyelemre méltó, mert egy integratív, rendszerszemléletű megközelítést preferál a sporttehetség-gondozás tekintetében; elméleti, valamint gyakorlati betekintést is nyújtva a témába.

A mü négy nagyobb fejezetből áll:

Az első fejezet a sporttehetség-fejlesztés integratív szemléletét prezentálja. Olyan témaköröket jár körbe, mint: a rendszerszemléletủ pszichológiai megközelítés, az emberi fejlödés folyamatai és a tehetség értelmezési keretei. A szerző nagy hangsúlyt helyez a komplexitás kérdéskörére és jól szemléltető példákkal támasztja alá azt a megállapítást, hogy minél inkább önmaga teljességében látjuk a különböző szintü (fizikai, érzelmi, értelmi és spirituális) müködéseink összességét, valamint a környezet szerepét, annál inkább képesek lehetünk önmagunk és mások fejlődését előmozdítani a kiteljesedés, az önmegvalósítás irányába.

A második fejezet a sporttehetség kibontakoztatását befolyásoló jelentősebb, egyénen belüli és személyközi pszichológiai tényezőkre fókuszál. Olyan interperszonális témákat érint, mint: az énkép, az (sport-)önbizalom, az arousal, a szorongás, a stressz, a coping-mechanizmusok, a figyelem, az intelligencia, valamint a flow. Az intraperszonális faktorok közül a család, az edzők és a csapattársak szerepét emeli ki. Többek között megtudhatjuk, hogy a sportolók nagyobb mértékben hallgatnak az edzőre, mint a szüleikre, továbbá hogy a sportszakmai szakértelem mellett a pedagógiai-pszichológiai szakértelem is elengedhetetlen.

A harmadik fejezetben egy labdarúgókkal végzett, nyomon követéses sporttehetségpszichológiai vizsgálatot mutat be a szerző, mely támpontokat nyújt a sporttehetség azonosításához, illetve tudományosan is alátámasztja az integratív megközelítés szükségszerüségét a tehetséggondozásban.

Végül, a negyedik fejezetben egy kitekintést kapunk az integratív szemléletü tehetségfejlesztés gyakorlati lehetőségei felé. Rövid leírást olvashatunk többek között a Competere tréningröl, valamint a sporttehetségpontok jelentőségéről.

A könyv egy koherens képet nyújt a téma iránt érdeklődőknek, struktúráját tekintve következetes, ami segíti a megértést, s a szerző tiszteletre méltó szakmai tudása inspirálóan hat. A személyes tapasztalatokra épülő szemléletes példák, valamint az átfogó kutatás érthető leírása kifejezetten gördülékennyé, egy élménnyé teszi az olvasást. 